\title{
Kansalaisyhteiskunta on demokratian juuristo
}

\author{
Aaro Harju (2010). Puheenvuoro kansalaisyhteiskunnan \\ tulevaisuudesta. Kansalaisfoorumi. 232 sivua.
}

Suomalainen kansalaisyhteiskunta ilmiönä syntyi sosiaalista mediaa lukuun ottamatta 1800-luvun loppupuoliskolla samassa tahdissa sivistyksen yleistymisen, elintason kohoamisen ja kansallisen heräämisen kanssa. Tuolloin syntyivät suuret kansanliikkeet, joista monet ovat kantaneet yli viime vuosisadan.

Yksimielisyys vallitsee siitä, että kansalaisyhteiskunta on kansanvallan kivijalka. Sille on ominaista autonomisuus, omaehtoisuus, aktiivisuus, vapaaehtoisuus, yleishyödyllisyys, yhteisöllisyys, paikallisuus, eettisyys ja solidaarisuus. Se sijoittuu amebamaisesti yhteiskunnan muiden sektoreiden lomaan, kuten Kansalaisfoorumin pääsihteeri Aaro Harju luonnehtii kirjassaan Puheenvuoro kansalaisyhteiskunnan tulevaisuudesta. Kansalaisyhteiskunta täydentää muuta yhteiskuntaa, mutta myös rajoittaa markkinoiden ja hallinnon valtaa. Anthony Giddensiin tukeutuen Harju jopa sanoo, etteivät markkinatalous ja demokraattinen valtio voi toimia tehokkaasti ilman kansalaisyhteiskunnan sivistävää ja balansoivaa vaikutusta. Kansalaisyhteiskunnan puitteissa siis ihmiset toimivat, osallistuvat ja vaikuttavat. Sen merkitys on verrattomasti suurempi sen vo- lyymiin, näkyvyyteen ja yleiseen arvostukseen nähden.

\section{TRENDEJÄ TUNNISTAMASSA}

Aaro Harju kartoittaa ne kehityssuunnat, joiden varassa pystyy arvioimaan myös kansalaisyhteiskunnan ja kansalaisaktiivisuuden kehitystä seuraavan $10-15$ vuoden aikana. Mihin siis olemme menossa?

Yleiset trendit tunnemmekin: globalisaatio, tietotekniikan tunkeutuminen miltei kaikkeen elämään, ilmastonmuutos, muut ympäristöongelmat, maahanmuutto ja monikulttuuristuminen, väestön ikärakenteen epätasapaino, tehokkuusvaateet ja niiden heijastuminen jaksamiseen ja ajankäyttöön, yhtenäiskulttuureiden katoaminen. Kansalaisyhteiskunta ei elä megatrendien ulkopuolella, vaan niiden ehdoilla.

2010-luvun kansalainen on postmoderni ihminen, joka haluaa yksilöllisiä valintoja, kokeilee, liukuu eikä helposti sitoudu. Se on myös kuva mielihyväänsä ja -halujaan maksimoivasta ihmisestä. Kansalaisyhteiskunnassa siitä seuraa, että osallistujien ja vapaaehtoisten mukaantulo ja sitoutuminen on ansaittava kerta kerralta uudelleen. Osallistuminen on muuttunut projektimaiseksi.
Velvollisuudentunnosta ei lähdetä kahta kertaa. Ihmiset haluavat pysyä vapaina seikkailijoina ja kuluttajina myös osallistumisissaan.

Erikseen ovat ne "identiteettiyhteisöt", urheiluseurat, uskonnolliset yhteisöt ja harrastuspiirit, joissa kansalaiset toteuttavat itseään tai jonne he hakeutuvat "omiensa" pariin.

Aktiivisuus kasautuu, myös kansalaisyhteiskunnassa. Hannu Kareisen käsitettä lainaten Harju puhuu varsin mittavasta Amoryhteiskunnasta, "antakaa meidän olla rauhassa". Siihen kuuluvat vetäytyvät yksityisyyteensä, viihdetarjonnan ja netin pariin, tai ovat suorastaan syrjäytyneitä. Harjun uskoo myös tulevaisuuden kansalaisyhteiskunnan kuvastavan ihmisten jakautumista. Näin kansalaisyhteiskunta on lähtenyt mukaan yhteiskunnassa vallitseviin jakoihin ja ryhmittymiin, vaikka sen omin rooli tulisi olla päinvastainen, yhdistäjä.

\section{MIHIN YHTEISKUNNAN PAUKUT PIISAAVAT?}

Eurooppalaisittain jyrkin väestörakennekehityksemme määrittelee pitkälle seuraavan 10-15 vuoden poliittisia päätöksiä, ellei siten lamauta poliitikkoja riittämättömiin nahkamunapäätöksiin. 


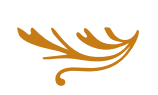

Työvoiman riittävyystutkimuksen mukaan (VATT 2010) yksistään kuntasektorille tarvitaan 130 000-170 000 uutta työntekijää turvaamaan väestön ikääntymisen vaatimat hyvinvointipalvelut nykyisellä tasolla. Se merkitsee sitä, että työelämään tulevat uudet ikäluokat pitäisi rekrytoida kokonaisuudessaan valtion ja kuntien palvelukseen, jotta täytetään eläkkeelle siirtyvien toimet ja virat.

Hoivan tuottaminen ja hätähuuto hoivan puolesta onkin Aaro Harjun mukaan yksi kansalaisyhteiskunnan suurista tehtävistä vuoden 2020/2025 Suomessa. Valtion taloudellisen tutkimuskeskuksen työvoimatarveselvityksen mukaan sosiaali- ja terveysalalla tarvitaan vuonna 2025 noin 80 000-120 000 ihmistä nykyistä enemmän hoitamaan vanhuusiän saavuttaneita ihmisiä. Kun sosiaali- ja terveysalalta lähtee samanaikaisesti eläkkeelle kymmeniä tuhansia ihmisiä, joka neljännen työikäisen suomalaisen tulisi laskelman mukaan työskennellä vuonna 2025 hoiva-alalla.

Suomessa arvioidaan olevan työikäisiä silloin noin kaksi miljoonaa. Puolen miljoonaa tulisi siis työskennellä hoitamassa vanhuksia. Yhtälö on kestämätön.

Harju pitäkin selviönä, että vuosien 2020-2025 Suomessa kansalaisyhteiskunta joutuu tuottamaan merkittävän osan ihmisten tarvitsemasta hoivasta ja huolenpidosta. Useimmiten se on omaishoitoa. Kansalaiset huolehtivat läheisistä ihmisistä ja kansalaisjärjestöt tuottavat tietyt terveys- ja sosiaalipalvelut perustamiensa yritysten kautta ja pieneltä osin järjestöllisenä toimintana. Maksupalvelutoimintaa kansalaisjärjestöjen ylläpitämänä siis.

Kivuttomasti tällainen siirtymä ei syntyne. Harju epäilee, että kymmenen, viidentoista vuoden kuluttua ihmiset ovat lähes kapinassa sen osalta, miten sairaita ja vanhuksia hoidetaan.

Harju puhuu "harmaista panttereista", ikääntyvistä vapaaehtoistyöntekijöistä, joita ilman yhteiskunta ei selviä. Mutta samalla hän kysyy, miten valmiita niukkuudesta itse aloittaneet ja pitkän työuran tehneet suuret ikäluokat ovat ryhtymään läheishoitajiksi tai kansalaisjärjestöjen vapaaehtoistyöntekijöiksi. Jo nyt 20000 suomalaista eläkeläistä muuttaa mieluummin talvikuukausiksi etelän aurinkoon velvoitteista vapaaseen elämään.

\section{LÄÄKETTÄ \\ DEMOKRATIAVAJEESEEN}

Keskeinen osa Aaro Harjun kirjas- sa käsittelee kansalaisyhteiskuntaa ja demokratiavajetta. "Demokratia on kriisissä", hän väittää.

Demokratiavajeella hän tarkoittaa muiden muassa sitä, että yhteiskunnalliset, kaikkia koskevat päätökset tehdään poliittisessa järjestelmässä, mutta kansalaisista vain noin kahdeksan prosenttia on jonkin puolueen jäseniä ja kaksi prosenttia puolueessaan aktiivisia. Suppea eliitti käyttää valtaa niin valtakunnallisella kuin kunnallisellakin tasolla.

Huolestuttavana hän pitää nuorten äänestyspassiivisuutta. Se kun jää pysyväksi käytännöksi.

Suomalaisilla nuorilla on varsin hyvät tiedot yhteiskunnallisista asioista, mutta kiinnostus politiikkaan ja yhteiskunnallisiin asioihin on laimeaa. Edustuksellisen demokratian vahvuus on kuitenkin siinä, että se pystyy kanavoimaan suuren ihmisjoukon näkemykset toteuttamiskelpoisiksi ratkaisuiksi. Ilman sitä yhteiskunnassa vallitsisi huutodemokratia ja vahvimman valta.

Vallan luisuminen virkamiehille ja poliittiselle eliitille johtuu asioiden monimutkaisuudesta ja runsaudesta sekä valmisteluprosessin pitkäkestoisuudesta. Suuremmat kuntakoot lisäävät entisestäänkin vallan etääntymistä. 


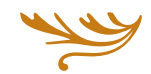

"Jos kansalaiset aiotaan saada aktiivisiksi, heidän on tunnettava itsensä tarpeellisiksi”, lainaa Harju Ajatuspaja e2:ta. Arkikokemus on monelle kuitenkin toisenlainen ja ihmiset kokevat jopa voimattomuutta päätöksenteon edessä.

Keinoiksi demokratiavajeeseen Harju tarjoaa kansalaisäänestysten harkittua lisäämistä, vuoropuhelun parantamista kansalaisten ja hallinnon välillä, aitojen kuulemisten lisäämistä, mielipidekartoituksia ja tietotekniikan hyväksikäyttöä äänestyksissä. Harju muuttuu liki idealistiksi edetessään kirjassaan deliberatiiviseen demokratiaan, jota Björn Wallén on käsitellyt pamfletissaan Kyllä kansalaisuudelle.

\section{DELIBERALISTINEN DEMOKRATIA}

Deliberalistisen demokratian lähtökohtana on kansalaisten saama etukäteistieto asioiden valmistelusta ja mahdollisuus keskusteluihin, väittelyihin ja vuoropuheluun. Sosiaalinen mediako avuksi? Ei sentään. Sosiaalisessa mediassa mielipiteet katoavat eetterin mustaan kitaan. Yhteisöllisen median rinnalle tarvitaan vakavampia osallistumisen ja vaikuttamisen areenoita. Ihmisiä tulee valtauttaa sillä, että he pääsevät lausumaan näkemyksensä asioista ennen päätöksentekoa ja he voivat muodostaa yhteistä mielipidettä.

Harjun mukaan deliberalistisen demokratian suuri vahvuus on se, että sen avulla saadaan arjen asiantuntemus ja ihmisten monipuolinen osaaminen yhteiseen käyttöön. Harju uskoo myös päättäjien joutuvan siinä uudella tavalla vastuulliseksi kansalaisille. Idealistista? Ehkä. Mutta lukija ainakin kaipaa tällaisia nostatuksia. Niitä oli viljalti myös 1800-luvun loppupuoliskolla ja niillä saatiin paljon aikaan: nykyisen sivistys- ja hyvinvointivaltion perusta.

Keskustelujen ja väittelyjen kanavoijina toimisivat siis kullakin yhteiskunnan erityissektorilla niihin asioihin erikoistuneet kansalaisjärjestöt. Näin yhteiskunnallisen roolin palautuminen kansalaisjärjestöille veisi kansalaisyhteiskuntaa kohti alkuperäistä ideaansa valtion vastapainona ja vallan kontrolloijana.

"Kansalaisjärjestöille sopii luontevasti ihmisten toiveiden ja tarpeiden äänitorvena oleminen", Harju muistuttaa.

Tässä hän sivaltaa vapaan sivistystyön suuntaan. Se kun on pitkään ollut sopeuttajan roolissa tarjotessaan ihmisille erilaisia itsensä kehittämisen ja harrastami- sen väyliä. Harju ehdottaa vapaan sivistystyön järjestöllisen rahoituksen ohjaamista juuri järjestötoiminnan uudistamiseen, ohjauksen suunnan muuttamiseen ja osaamisen väkevään parantamiseen. "Tällöin valtion koulutuksellinen tuki olisi oikeassa tarkoituksessa”, hän kirjoittaa.

\section{KETTERÄT SYRJÄYTTÄVÄT HITAASTI KÄÄNTYVÄT LAIVAT}

Suomi on järjestöjen maa. Silti meillä on ehkä tuhansittain järjestöjä, jotka ovat henkitoreissaan siksi, ettei niihin saada vastuunkantajia, puheenjohtajia, joka paikan höyläksi yltäviä sihteereitä ja muita rutiineiden pyörittäjiä. Luottamustoimet eivät enää aikoihin ole olleet tavoiteltuja, itsetuntoa hiveleviä paikkoja.

Samanaikaisesti syntyy uusia yhteisöjä kuin sieniä sateella. $\mathrm{Ne}$ ovat keveitä, usein yhden asian ympärille kasvaneita ryhmittymiä. Kun ihmisten vapaa-aika on rajallinen, kilpailu ihmisten ajasta on kansalaisyhteiskuntatasolla kova. Häviäjiä ovat useimmiten suuret, vanhat järjestöt.

Tulevaisuus on Harjun mukaan erilaisissa väljissä yhteenliittymissä ja toimintaryhmissä, joissa ohitetaan tähän asti vallinnut hierarkkinen organisaatio paikallis- 
yhdistyksineen, piirijärjestöineen ja valtakunnallisine liittoineen. Suora jäsenyys ja vaikuttaminen lisääntyvät.

Menestyjiä ovat "älykkäät järjestöt", jotka osaavat lukea oikein ajan merkit ja kykenevät uudistumaan toimintatavoissaan. "Vain konservatiivisimpia kiinnostaa hoitaa järjestöjen hallinnollisia asioita sata vuotta vanhoin menetelmin”, paukuttaa Harju ja vannoo järjestöasioiden moderniin hoitamiseen virtuaalisesti.

\section{YHTEISÖLLINEN MEDIA EI RATKAISE}

Kansalaisyhteiskunnasta ei voi kirjoittaa käsittelemättä yhteisöllistä mediaa. Sille kirjassa on omistettu oma osionsa. Teoksessa Suomalaiset osallistujina tutkija Heli Pessala toteaa (ja Harju lainaa), että vuoteen 2020 mennessä verkko on muodostunut vaikutuskanavaksi ainoastaan "tietyissä ryhmissä ja osallistumistavoissa", muttei laajasti kansalaisia koskevana. Verkko siis toimii uutena osallistumiskanavana vain jo ennestään poliittisesti aktiivisille ihmisille. Enimmälle osalle se on ei-poliittisten teemojen foorumi.

Aaro Harju kuuluu keskeisimpiin kansalaisaktiivisuusasiantuntijoihimme. Pitkäaikainen harrastaneisuus näkyy hänen pohdinnoissaan, joiden vakuutena on laaja perehtyneisyys tutkimukseen ja kirjallisuuteen. Lukijan on näin helppo päätellä, millainen kantti kirjoittajalla kulloinkin on esittämiinsä väittämiin ja arvioihin.

\section{Anneli Kajanto}

julkaisupäällikkö, Kansanvalistusseura; toimituspäällikkö, Aikuiskasvatus 